\title{
Detection of Extended Spectrum B-Lactamases Among Bacteria Isolated from Snacks Sold Within Kaduna State Metropolis Northwest Nigeria
}

\author{
Edward Deborah Shetu ${ }^{1}$, Muhammad Yusha' ${ }^{2}{ }^{2}$, Auwalu Uba $^{3}$, Ogboi Johnbull Sonny ${ }^{4}$, \\ Edward Isaac Usman ${ }^{5}$ \\ ${ }^{1}$ Department of Microbiology, Faculty of Science, Kaduna State University, Kaduna, Northwest Nigeria \\ ${ }^{2}$ Department of Microbiology, Faculty of Science, Bayero University, Kano, North-west Nigeria \\ ${ }^{3}$ Department of Microbiology, Faculty of Science, Abubakar Tafawa Balewa University, Bauchi, Northeast Nigeria \\ ${ }^{4}$ Department of Microbiology Jedima International Health Consult Ltd, Lagos, Southwest Nigeria \\ ${ }^{5}$ Department of Medical Laboratory, Federal Neuropsychiatric Hospital, Medical Microbiology Lab Barnawa, Kaduna, Northwest Nigeria
}

Email address:

debbiagidi@yahoo.com (E. D. Shetu)

\section{To cite this article:}

Edward Deborah Shetu, Muhammad Yusha u, Auwalu Uba, Ogboi Johnbull Sonny, Edward Isaac Usman. Detection of Extended Spectrum B-Lactamases Among Bacteria Isolated from Snacks Sold Within Kaduna State Metropolis Northwest Nigeria. American Journal of

Laboratory Medicine. Vol. 2, No. 5, 2017, pp. 84-89. doi: 10.11648/j.ajlm.20170205.11

Received: March 15, 2017; Accepted: April 21, 2017; Published: October 24, 2017

\begin{abstract}
Extended spectrum $\beta$-lactamses (ESBL) are a group of plasmid mediated, diverse, complex, and rapidly evolving enzymes that are posing a major therapeutic challenge today in the treatment of hospitalized and community patients. Due to non-regulation of snacks, people are exposed to pathogenic bacteria. The aim of this study is to detect extended spectrum $\beta$ lactamases among bacteria isolates from snack foods sold in Kaduna metropolis Nigeria. A total of 144 samples comprising of meat-pie, doughnut, egg-roll, buns, samosa, burger and pizza were cultured on blood agar, McConkey agar and Cysteine Lactose Electrolyte Defficient Agar, for the presence of pathogenic bacteria. The isolated organisms were subjected to biochemical tests for identification using standard procedures. The isolates were screened for Extended Spectrum $\beta$-lactamase

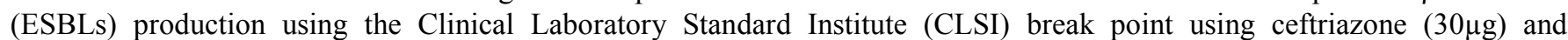
cefotaxime $(30 \mu \mathrm{g})$. Suspected ESBLs producing organisms from screening tests were subjected to double disc synergy test (DDST) for confirmation and standard discs of Augmentin $(30 \mu \mathrm{g})$. Out of the 144 snack samples analysed, 24 Gram negative entericbacteria were isolated and these includes: Citrobacter freundii 6(25\%), Echerichia coli 1(4.2\%), Enterobacter sp. 2(8.3\%), Klebsiella pneumonia 7(29.2\%), Proteus mirabilis 1(4.2\%), Serratia marcenscens 4(16.7\%), Morganella morganii 1(4.2\%), providencia sp. 1(4.2\%) and Shigella sp. 1(4.2\%). Detection of ESBL among Gram-negative isolates based on CLSI revealed that $16(66.7 \%)$ of the isolates were ESBL producers while $37.5 \%$ were confirmed as ESBLs producers using Double Disc Synergy Test. Statistically, there was a significant relationship between the different beta-lactamases producing isolates $(P<0.05)$.It also showed a significant relationship between the occurrences of beta-lactamase producing isolates among the different snacks $(P<0.05)$ This study indicated that snack foods can be contaminated by ESBLs producing bacteria and may result to infections following consumption by humans which have public health implications for the general public.
\end{abstract}

Keywords: Snacks, Beta-Lactamase, Gram Positive, Gram Negative

\section{Introduction}

Beta-lactamase are enzymes produced by some bacteria that provide resistance to $\beta$-lactam antibiotics like penicillins, cephalosporins, and carbapenems (ertapenem), although carbapenems are relatively resistant to beta-lactamase. $\beta$ etalactamase provides antibiotic resistance by breaking the antibiotics 'structure. These antibiotics have a common 
element in their molecular structure of a four-atom ring known as a $\beta$-lactam. However, through hydrolysis the lactamase enzyme breaks the $\beta$-lactam ring open, deactivating the molecule's antibacterial properties. Betalactam antibiotics are typically used to treat a broad spectrum of Gram-positive and Gram-negative bacteria. ßeta-lactamase produced by Gram-negative organisms are usually secreted, especially when antibiotics are present in the environment [1].

Extended Spectrum $\beta$-Lactamase were first described in 1980s and have been detected in Klebsiella $\mathrm{s} p$ and later in Escherichia coli, Pseudomonas aeruginosa, Serratia marcescens and other Gram-negative bacilli. Extended Spectrum $\beta$-Lactamase are enzymes conferring broad resistance to penicillins, Aztreonamand Cephalosporins. These enzymes are able to hydrolyze $3^{\text {rd }}$ and $4^{\text {th }}$ generation Cephalosporins and Monobactams. They are an increasing important cause of transferable multidrug resistance in Gramnegative bacteria throughout the world [2]. One of the important features of Extended Spectrum $\beta$-Lactamase producing strains is resistant to multiple clinically important antibiotics [3].

Snacks have been described as "high-energy" foods which are composed of nutrients such as carbohydrate, fat and oil, protein and water. They include: meatpie, eggroll, doughnut, chin-chin, sausage, puff-puff and also crispso fall types such as meat or fried fish and also African dish like moi-moi and bean cake, etc. Theseare usually consumed by all age groups in the society at large, but mostly youths in various institutions and also school children. They are described as ready to Eat Foods (RTE), because of their status as food being ready for immediate consumption at the point of sale [4].

The consumption of snacks is due to the convenience of modern lifestyle, economic downturn, industrialization, materialism, the quest for more wealth, lack of time to prepare a proper meal and the low purchasing power [5].

The major concern with ready-to-eat food (snacks) is their microbiological safety mainly because vending prepare such food in places that may have poor sanitation. In some African countries, such food shave tested positive for various microorganisms of public health concern, including faecal Coliforms Escherichia coli, Staphylococcus aureus, Salmonella sp, and Bacillus cereus. A study conducted in 2011 by Oranusi and friends observed that the presence of Escherichia coli, Enterococcus, Klebsiella sp. And Staphylococcus aureus are of concern and further support the possibility of faecal contamination of product due to poor sanitation $[6,7]$.

Snacks (RTE) are regarded as potentially hazardous because such foods can support the growth of pathogens which can result in food borne disease, resulting from the ingestion of the bacterial pathogens and their toxins as documented worldwide [8]. The microbial agents that cause food borne illness may include bacteria such as Salmonella, Staphylococcus aureus, Escherichia coli (pathogenic trains), Bacillus spp, Clostridium botulinum, Pseudomonas aeruginosa, viruses such as Hepatitis A and E, fungi such as mold and yeasts $[9,10]$. The nature of these foods and their method of preparation, which involves extensive handling make them prone to contamination and cross contamination from soil, water, air, human activities (baking and sales) storage and distribution facilities. How ever a number of foods in Nigeria have been reported to have high level of contaminants [11].

In 2007, World Health Organisation estimated that a significant proportion of the approximately 1.5 billion episodes of diarrhea and more than three million deaths globally recorded annually results from the consumption of food with microbial pathogens and toxins [9].

These bacteria are present in soil as environmental contaminants and opportunistic pathogens which are abundant in human body (skin, nail and hair), water and air and hence can be easily present in these foods, due to handling, processing, transportation and storage [5, 12]. Hazards in the forms of microbial contamination and ultimately foodborne illness will occur when consuming such products.

More attention has been focused on hospitals as the primary reservoir and place of transmission of many antimicrobial-resistant organisms, but there is a need to shift interest to the role of non-hospital community, such as foods, as a significant reservoir of resistant pathogens [13]. A general observation of our society shows a social pattern characterized by increased mobility due to urbanization, large number of itinerant workers and less family or home centred activities resulting in a large percentage of the population depending on ready-to-eat foods for employment and food. This situation, however, has resulted that food sanitary measures and proper food handling have been transferred from individual, families to the food vendors who rarely enforce such practices [14]. The major concern with ready-to-eat food (snacks) is their microbiological safety mainly because vending is done in places that may have poor sanitation. $\beta$-lactamase producing bacteria are important in polymicrobial infections [14]. They have a direct and indirect impact in causing infection through their ability to produce the enzyme $\beta$-lactamase [15]. Hence there is a critical need for microbiological quality evaluation of snacks to as certain their safety standard. Therefore the aim of this study was to detect extended spectrum $\beta$-lactamase among pathogenic bacterial isolated and to confirm extended spectrum $\beta$ lactamase producing isolates using Double Disc Synergy Test (DDS )from snack foods sold within Kaduna metropolis.

\section{Materials and Methods}

\subsection{Study Site}

Kaduna is the capital of defunct Northern Region States with coordinates at $10^{\circ} 32^{\prime} 23^{\circ} \mathrm{N} 7^{\circ} 26^{\prime} 25^{\circ} \mathrm{E}$ North-west Nigeria with total area of $131 \mathrm{Kmq}$ (51sqmi), a cosmopolitan town where every kind of food is sold. It is the present 
capital of Kaduna State.

\subsection{Sample Collection.}

A total of one hundred and forty four (144) snacks samples comprised of meatpie, buns, eggroll doughnut, sausageroll, burger, samosa, were purchased froms tandardeateries, localkiosks, and street hawkers located in Sabo Tasha, Barnawa, Central Market, KASU and some Hospital environment. Samples were aseptically collected in a clean polyethylene bag and transported immediately to the laboratory for analysis.

\subsection{Sample Experiments}

The sample analysis was done using the standard recommended procedure. Ten $(10 \mathrm{~g})$ gram seach of the sample were blended and inoculated into peptone water and incubated at $37^{\circ} \mathrm{C}$ for 24 hours. The 24 hours homogenate was then inoculated on to MacConkey agar (Oxoid), Cysteine Lactose Electrolyte Deficient (CLED) agar and Chocolate agar plates for isolation of enterobacteriaceae. The inoculated plates were incubated aerobically at $37 \mathrm{oC}$ for $24-$ 48hours for colony formation [28].

\subsection{Morphological and Biochemical Characterization of the Isolates}

Morphological and biochemical characterization of the pure isolates obtained was carried out as described by Monica Cheesbrough [16].

\subsection{Detection of ESBL Producing Gram-Negative Isolates from the Snacks}

\subsubsection{Screening Test for ESBL Producers}

A Mueller Hinton agar plate was incubated with the test isolates.Then Cefotaxime $(30 \mu \mathrm{g})$ and Ceftriazone $(30 \mu \mathrm{g})$ single disc were used alone. The discs were placed $20 \mathrm{~mm}$ apart and incubated aerobically at $37^{\circ} \mathrm{C}$ for 24 hours. Diameters of the zones of growth inhibition were measured using a transparent metricruler.

\subsubsection{Phenotypic Confirmatory Test (Double Disc Synergy Test)}

A sterile Mueller Hinton agar was prepared and a 0.5 McFarland equivalent standard of the test isolates was streaked on the surface of the agar with a sterile loop and allowed for 15-20 minutes to pre-diffuse. An Augmentin disc (containing amoxicillin $10 \mu \mathrm{g}+$ clavulanicacid $20 \mu \mathrm{g}$ ) was placed at the centre of the plate, Ceftriazone $(30 \mu \mathrm{g})$, and Cefotaxime $(30 \mu \mathrm{g})$ each were placed $20 \mathrm{~mm}$ apart (centre to centre) with a sterile forceps. These were incubated at $37 \mathrm{oC}$ for 24hours. Diameters of the zones of growth inhibition were measured using a transparent metric ruler. An enhanced inhibition zone of $5 \mathrm{~mm}$ and above of any one of the test antibiotics towards the augmentin disc was regarded as positive for phenotypic production of ESBL enzyme. [17]

\section{Result}

This study revealed that among the 144 samples cultured, 34 revealed bacteria growth accounting for $23.61 \%$ of the total samples analysed. The various organisms isolated from the respective cultures include: Citrobacter freundii, (6) Escherichia coli, Klebsiella pneumonia, Serratia marcenscens, Provindencia species, Enterobacter species, Staphylococcus aureus, Proteus mirabilis, Shigella species, and Morganella marganii. The various biochemical tests revealed the following percentage occurrences Citrobacter freundii 6(25\%), Enterobacter species 2(8.3\%), Escherichia coli 1(4.2\%), Klebsiella pneumonia 7(29.2\%), Morganella marganii 1(4.2\%), Proteus mirabilis 1(4.2\%), Provindencia species(4.2\%), Serratia marscenscens 4(16.7\%), Shigella species 1(4.2\%) as shown in (Table1). Detection of Extended Spectrum Beta Lactamase using cefotaxime and ceftriazone revealed the presence of Beta lactomase among sixteen out of the twenty four isolates. $100 \%$ of the number of Escherichia coli, Enterobacter species and Proteus mirabilis screened revealed the presence of ESBLs enzymes while $85.7 \%$, $33.3 \%$ and $16.67 \%$ of Klebsiella pneumoniae, Citobacter fruendii, and Serratia marcenscens respectively revealed the presence of ESBLs enzyme as shown in (Table 2). How ever this enzyme was not observed in Shigella species, Morganella morganii and Providencia species as shown in (Table 3).

Table 1. Biochemical Characteristics of Gram-negative Bacteria isolated from Snacks.

\begin{tabular}{|c|c|c|c|c|c|c|c|c|c|c|c|c|c|}
\hline \multirow[t]{2}{*}{ Isolate } & \multicolumn{11}{|c|}{ Biochemical Characteristics } & \multirow{2}{*}{$\begin{array}{l}\text { No. } \\
\text { identified }\end{array}$} & \multirow{2}{*}{$\begin{array}{l}\% \\
\text { occurrence }\end{array}$} \\
\hline & Lac & Urea & Cit. & Mot. & MR & VP & $\mathbf{H}_{2} \mathbf{S}$ & Gas & Butt & Slope & Ind. & & \\
\hline Citrobacter fruendii & $\ldots+$ & $-/+$ & + & + & + & - & $+/-$ & + & $\mathrm{Y}$ & $\mathrm{R} / \mathrm{Y}$ & - & 6 & 25.0 \\
\hline Enterobacter species & + & - & $+/-$ & + & & - & - & + & $\mathrm{Y}$ & $\mathrm{Y}$ & - & 2 & 8.3 \\
\hline Escherichia coli & + & - & - & + & + & - & - & $+/-$ & $\mathrm{Y}$ & $\mathrm{Y}$ & + & 1 & 4.2 \\
\hline Klebsiella pneumoniae & + & $\ldots+$ & - & - & & & - & + & $\mathrm{Y}$ & $\mathrm{Y}$ & $+/-$ & 7 & 29.2 \\
\hline Morganella morganii & - & + & - & + & + & - & - & + & $\mathrm{Y}$ & $\mathrm{R}$ & + & 1 & 4.2 \\
\hline Proteus mirabilis & - & + & + & + & + & - & + & + & $\mathrm{Y}$ & $\mathrm{R}$ & - & 1 & 4.2 \\
\hline Shigella species & - & - & - & - & + & - & - & + & $\mathrm{Y}$ & $\mathrm{R}$ & - & 1 & 4.2 \\
\hline Provindecia species & - & + & + & + & + & - & - & + & $\mathrm{Y}$ & $\mathrm{R}$ & + & 1 & 4.2 \\
\hline
\end{tabular}

$\mathrm{Lac}=$ lactose $, \mathrm{Cit}=\mathrm{Citrate}, \mathrm{Ind}=$ indole, $\mathrm{H}_{2} \mathrm{~S}=$ hydrogen sulphide production, $\mathrm{Mot}=$ motility

$\mathrm{R}=$ Alkaline reaction, $\mathrm{Y}=$ Acid reaction, $+=$ Late positive reaction, $+/==$ few species give negative reaction 
Table 2. Occurrence of ESBLs among the Gram negative Bacterial Isolates Based on CLSI Break point.

\begin{tabular}{lllll}
\hline s/n & Isolates & No.screened & No positive & \%occurrence \\
\hline 1 & Citrobacter fruendii & 6 & 2 & $8.33(33.3)$ \\
2 & Enterobacter species & 2 & 2 & $8.33(100)$ \\
3 & Escherichia coli & 1 & 1 & $4.17(100)$ \\
4 & Klebsiella pneumonia & 7 & 6 & $25(85.7)$ \\
5 & Morganella morganii & 1 & 0 & $0(0.0)$ \\
6 & Proteus mirabilis & 1 & 1 & $4.17(100)$ \\
7 & Serratia marcescens & 4 & 4 & 16.67 \\
8 & Shigella species & 1 & 0 & 0.00 \\
9 & Provindencia species & 1 & 0 & 0 \\
Total & & 24 & 16 & $60.0)$ \\
\hline
\end{tabular}

Table 3. Confirmation of ESBL among the Gram-negative Bacteria isolates base on Double Disc Synergy Test (DDST).

\begin{tabular}{|c|c|c|c|c|c|}
\hline S/no & Isolates & No.screened & No.positive & No confirmed positive & \%occurrence \\
\hline 1 & Citrobacter fruendii & 6 & 2 & 1 & $6.25(16.67))$ \\
\hline 2 & Enterobacter species & 2 & 2 & 0 & $0(0.0)$ \\
\hline 3 & Escherichia coli & 1 & 1 & 1 & $6.25(100)$ \\
\hline 4 & Klebsiella pneumoniae & 7 & 6 & 3 & $18.75(42)$ \\
\hline 5 & Morganella morganii & 1 & 0 & 0 & $0(0.0)$ \\
\hline 6 & Proteus mirabilis & 1 & 1 & 1 & $6.25(100)$ \\
\hline 7 & Provindencia species & 1 & 0 & 0 & $0(0.0)$ \\
\hline 8 & Serratia marcescens & 4 & 4 & 3 & $18.75(75)$ \\
\hline 9 & Shigella sspecies & 1 & 0 & 0 & $0(0.0)$ \\
\hline Total & & 24 & 16 & 9 & 37.5 \\
\hline
\end{tabular}

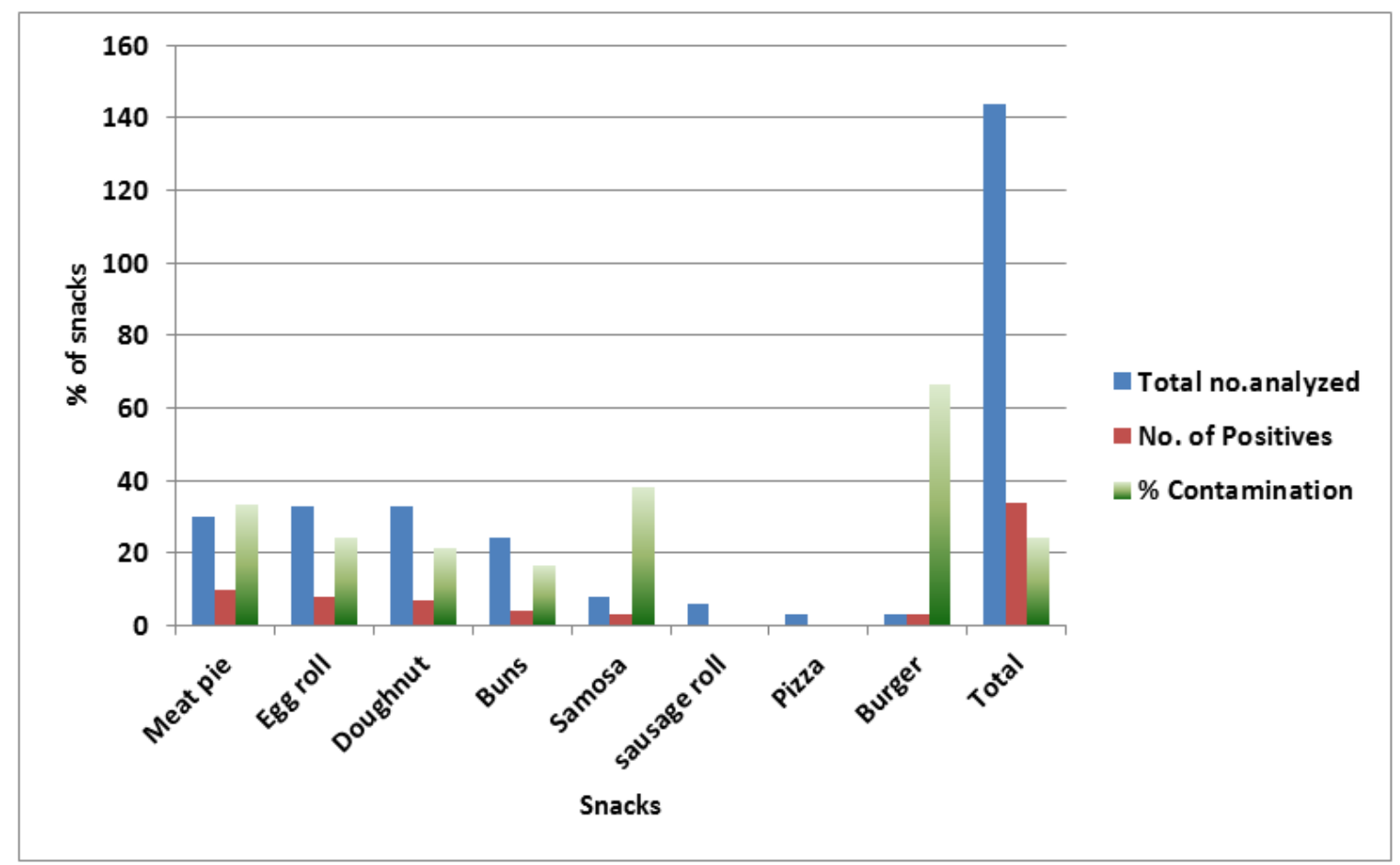

Figure 1. Graph showing bacteria contamination of snacks.

\section{Discussion}

In this research, the various organisms isolated from the respective cultures include : Citrobacter freundii, Escherichia coli, Klebsiella pneumoniae, Serratia marcenscens, Provindencia species, Enterobacter species, Staphylococcus aureus, Proteus mirabilis, Shigella species, and Morganella marganii.

From the biochemical characteristics of the enterobacteriaceae isolated from this research, it could be observed that Klebsiella sp, are $7(29.3 \%)$, Citrobacter fruendii 6(25.0\%), and Serratia marcenscens 4(16.2\%). E.coli, Proteus mirabilis, Morganella morganii, Providencia species and Shigella species had one isolate representing 
$(4.2 \%)$ each, this is similar to the work of Yusha $u$ et al who isolated $5(31.25 \%)$ Citrobacter freundii, one isolate of Proteus and E.coli each from commercial foods [19].

The clinical importance of ESBL makes it necessary to screen and confirm the presence of these bacteria in nonhospital community, such as food as a significant source of pathogens $[13,18]$. In this current investigation, out of the 24 isolates subjected to ESBL screening 16(66.67\%) were found to be ESBLs positive, while 9(37.5\%) were confirmed to be positive for ESBL producers based on the DDST (table 2). This values are considered high when compared to the work of Yusha'u et al., [19] which shows $7(63.64 \%)$ of the enterobacteriaceae to be positive for ESBL and confirmed $4(57.14 \%)$ as positive for ESBL production from commercial drinks. Also from the research of Adenike, et al, [20], on ESBL producing E.coli, it was discovered that $18(45 \%)$ were ESBL producers .This research revealed $100 \%$ ESBL producing E.coli and Proteus mirabilis which is higher than that discovered by Adenike et al. [21]

The high occurrence of the enterobacteriaceae ESBLs pathogenic bacteria may be due to poor hygienic practice which may result in some of then on-producing ESBL isolates acquiring plasmids that are responsible for ESBL production since plasmid scan easily be transferred between organisms living in the same environment and replicate along side bacterial chromosome. [22, 23].

The ESBL producers obtained from this research possessed the ability to hydrolysed B-lactam antibiotics containing an oxyiminogroup such as Augumentin (amoxicillin and clavulanic acid), ceftriazone and cefotaxime which are usually inactivated by b-lactam inhibitors. The production of B-lactamase remains the major mechanism of resistance in Gram-negative bacilli to B-lactam antibiotics. In recent years, Extended-Spectrum blactamases (ESBLs) have become progressively wide spread due to extensive use of third generation cephalosporins in Hospital settings [24].

In this study, $37.5 \%$ of ESBL-positive isolates was revealed, and this is quite higher compare to the work which recorded $24.3 \%$ in are search conducted in hospitalized patients in Curitiba, southern Brazil [24]. The occurrence and distribution of ESBL differs from Country to Country and from Hospital to Hospital [24]. The high occurrence of ESBL in Klebsiella observed in this study is of great concern since infections caused by this bacteria (particularly respiratory tract infections) are very common in the Northern part of Nigeria due to the contagious nature via the weather condition and the resistance of the organisms to harsh conditions, which may be due to the presence of capsules that gives some level of protection [25, 26].

Statistically, a 2-tailed t-test showed a significant relationship between the different beta- lactamase producing isolates $(\mathrm{P}<0.05)$. It also showed a significant relationship between the occurrences of beta-lactamase producing isolates among the different snacks $(\mathrm{P}<0.05)$.

\section{Conclusion}

The study has established the presence of pathogenic bacteria in snacks sold within Kaduna Metropolis which are ESBLs producers and are multi-drug resistant.

The study further revealed that snacks are contaminated by enterobacteriaceae which possess the ability to produce the Blactamase enzyme. The high occurrence of the Extended Spectrum B-lactamase producing bacteria in snacks as established in this study call for hygienic handling of these snacks both during preparations and storage in order to avoid contamination by pathogenic bacteria.The study also suggested that most contaminations are via equipment to packaging as well as handling. Therefore, vendors should been lightened on standard hygienic methods of handling snacks.

\section{References}

[1] Neu H C (1969). "Effect of beta-lactamase location in Escherichia coli on penicillin synergy". Applied Microbiology 17(6):783-6.PMC377810.PMID4894721.

[2] Bali B E, Acik Land Sultan N, (2010), Phenotypic and molecular characterization of SHV,TEM,CTX-Mand extended-spectrum $\beta$-lactamase produced by Escherichia coli,Acinobacter baumannii and Klebsiella isolates in a Turkish hospital, African. Journal of Research.,4(8):650-654 http://www.academicjournals.org/ajmr

[3] Shacheraghi F, Shakibaie M R and Noveiri H, (2010), Molecular identification of ESBL genes blaGES-1, blaVEB-1, blaCTX-M, blaOXA-1, blaOXA-4, blaOXA-10andblaPER1in Pseudomonas aeruginosa strains isolated from burn patients by PCR, RFLP and sequencing techniques. Int. J. Biol. LifeSci., 6(3):138-142.

[4] Lovet T, Kigigha and Henry C. (2012). Bacteriological characterization of snacks sold in River State University of Science and Technology, Port Harcourt, Nigeria. African Journal of Biochemistry Research 6(3).39-45.

[5] Nielsen, A. C., (2006). Consumers and ready-to eat meals: $A$ global AC Nielsen report. ACNielsenInc., USA http://dk.nielsen.com/reports/Globa 1RTE ReportDec06.pd.

[6] Oranusi, S. Omagbemi, F. and Eni A. O (2011). Microbiological Safety Evaluation of Snacks sold in fast food shops on Ota, Ogun State, Nigeria. Research Journal of Biological Sciences: 6(7) pp.309-3139.

[7] Hazariwala J K, and Donovan T. Guidelines for the microbiological quality of some ready-to eat foods samples at the point of sale. Communicable Disease and Public Health 2002; 3:163-167.

[8] WHO, (2007). Food safety and food borne illness factsheet. World Health Organization Geneva, Switzerland.

[9] Centre for Disease Control (CDC), (2010). Preliminary Food net data on the incidence of infection with pathogen stransmitted commonly through food. Morbidity and mortality weekly Report, 59:418-422.

[10] Oluwafemi F and Simisaye M T (2005). Extent of microbial contamination of sausage sold in two Nigeria cities. African Journal Biomedical Research; 9: 133-136. 
[11] Oranusi S U, Galadima M, Umoh V J and Nwanze P I (2007). Food Safety evaluation in boarding schools in Zaria, Nigeria using the HACCP System. Scientific Research. Essay, 2:426433. Organization Geneva, Switzerland.

[12] Hunter P R, Wilkinson D C, Catling L A and Barker G C, (2008), Meta-analysis of experimental data concerning antimicrobial resistance gene transfer rates during conjugation. Applied Enviromental Microbiology.,74(19)6085.

[13] Musa O Iand Akande T M (2002). Effect of health education intervention or food safety practice among food vendors in Ilorin. Sahel Med.J.5:120-124.

[14] Jarlier V, Nicholas M. H, Fournier G, Philippon A (1988). Extended broad-spectrumbeta-lactamases conferring transferable resistance to newer beta-lactam agents in Enterobacteriaceae: hospital prevalence and susceptibility patterns. Review infectious diseases 10:867-878.

[15] Rooney P. J. O'Leary M., Loughary A. C. Mcmacmaont M. Smith B. Donaghy P. Badri M. Wordford N. Karisik E. Livermore D.M.(2009). Nursing homes as a reservoir for extended spectrum bets lactamases (ESBL) producing ciproflozacin resistant E.coli. journal of antimicrobial chemotherapy 64: $653-641$.

[16] Yusha'u M, Umar M. Iand Suleiman K,(2010). Indigenous commercial drinks as potential sources of extended spectrum $\beta$-Lactamases (ESBL) producing organisms in Kano-Nigeria. International Journal of Biomedical and Health Sciences. 6(1).

[17] Adenaike O. Olonitola O. S. Ameh J. B .and Whong C. M. Z (2013). Incidence of Extended Spectrum $\beta$-Lactamases producing bacteria and multi drug resistances trains from processed meat'suyu'sold in a university community. The international Journal of Engineering and science (IJES). ISSN(e):2319-1813ISSN(p):2319-1805.
[18] Gunseren F., Mamikoglu L. Ozturk S. Yucesoy M. Biberoglu K.YulungN.DoganayM.SumerkanB.Kocagoz S. Unal S.Cetin S.Calangu S. KoksalI .Leblebicioglu H.and Gunaydin M.(1999). A surveillance study of antimicrobial lresistance of gram-negative ebacteria isolated from Intensive care units in Eight hospitals in Turkey. Journal of antimicrobial Chemotherapy43:373-378.

[19] Bradford A. Patricia (2001): Extended-Spectrum $\beta$ Lactamases in the $21^{\text {st }}$ Century: Characterization, Epidemiology, and Detection of this Important Resistance Threat. Clinical Microbiology Reviews.14(4)933-951.

[20] Paterson D L, Bonomo R A (2005) .Extended Spectrum $\beta$ Lactamases: A Clinical Update. Clinical Microbiology Review 18:657-86.

[21] Yusha'u M., Adakawa M. I and Kawo A. H (2011) Prevalence of extended spectrum $\beta$-Lactamase (ESBLs) among Clinical Enterobacteriaceae isolates obtained from private diagnostic laboratory in Kano, Nigeria. International Journal of Biological and Chemical Sciences 5(1):365-370.

[22] Thomas, B. T Shoyemi, W. R, Kolawole, R. M, Gbadamosi, K. P (2013). Incidence and Resistance pattern of Bacteria associated with Street foods in Ogun State, Nigeria. NewYork Science Journal. 6(9).pp.80-83.

[23] Yusha'u M., Abubakar H. M., Kawo A. H (2010) .Commercial foods as potential sources of extended spectrum $\beta$-Lactamases (ESBLs) producers in Kano-Nigeria. International Journal of Pharmceutical and Applied Sciences. $1(1)$.

[24] Monica Cheesbrough (2003) ;District Laboratory practice in Tropical Countries Part 2. 